Non-peer reviewed preprint submitted to Journal of Volcanology \& Geothermal Research

1 Basement sliding and the formation of fault systems on Mt Etna volcano

2

3 by John B. Murray and Ben van Wyk de Vries.

4

5 This manuscript is a non-peer reviewed preprint of a paper submitted for publication in the 6 Journal of Volcanology and Geothermal Research. 


\section{Basement sliding and the formation of fault systems on Mt Etna volcano}

John B. Murray ${ }^{1} \&$ Ben van Wyk de Vries $^{2}$

${ }^{1}$ School of Environment, Earth \& Ecosystem Sciences, The Open University, Walton Hall, Milton Keynes MK7 6AA, Great Britain j.b.murray@open.ac.uk

${ }^{2}$ Laboratoire Magmas et Volcans, Université Clermont Auvergne, Observatoire du Physique du Globe de Clermont, UMR6524-CNRS, Campus Universitaire des Cézeaux, 6 Avenue Blaise Pascal, TSA 60026 - CS 60026, 63178 Aubiere, Cédex, France

\section{Abstract}

The influence of faulting on the eruptive mechanisms of Mt Etna has been intensively studied, especially regarding the importance of regional tectonics, magma pressure, gravitational spreading and east flank instability. Here we examine the influence of an additional process: the wholesale sliding of the Etna massif along its sloping basement. Using laboratory analogue experiments, we create a series of model volcanoes on sloping basements, with obstructions to represent the mountains and hills surrounding Etna, and an unconstrained downslope edge to represent the unbuttressed seaward slopes. We find that analogues of all the Etna fault systems can be produced in the same model. Furthermore, we find that the relative velocities of transcurrent faulting and extension of each model flank fault system match those of Mt Etna in every case. We also find convincing evidence that gravitational spreading of the summit cone, combined with downslope sliding, controls the position of future eruptive vents around the summit, by creating faults and fractures that form paths of least resistance for magma intrusions. The intruding magma in turn augments fracture opening by an order of magnitude, in a feedback process that dominates within the summit graben. We conclude that gravitational spreading and sliding are the dominant processes in creating faults at Etna, and that these two processes, augmented by magma pressure, are responsible for the rapid seaward movement of the eastern slopes, tectonically cut off from the stable western flanks. The influence of regional tectonism is up to two orders of magnitude lower. The conceptual model derived here could make an important contribution to the investigation and monitoring of eruptive, seismic and landslide hazards, by providing a unified mechanical system that can be used to understand deformation.

KEYWORDS:

Volcano Tectonics

Gravitational spreading

Etna volcano

Basement sliding

Volcano instability

Eruption mechanism

Faulting 


\section{Figures 1 and $\mathbf{2}$ in colour}

1. Introduction

The flanks of Mt Etna are dissected by large numbers of active fault systems, particularly on the eastern side of the volcano. These faults are key to understanding the tectonic and eruptive mechanisms of one of the world's most active volcanoes. In the past, the disposition of Etna faults were ascribed to stress regimes associated with the regional tectonic setting of eastern Sicily (Rittmann 1973, Grindley 1973, Lo Giudice et al 1982). More recently, the effect of magma pressure accompanying dyke intrusion over a long period has been recognised (Walker 1992, Tibaldi and Gropelli 2002, Solaro et al 2010, Murray 2019). The advent of gravitational spreading as a major volcanic process (Borgia 1992, 1994) and the recognition of the east flank instability of Etna (Murray et al. 1994, Rasa et al 1996, Rust \& Neri 1996, Acocella et al. 2013, Urlaub et al 2018) has led to greater understanding of how these faults are related to gravitational stresses induced as the Etna edifice deforms under its own weight.

In this paper, we consider the additional effect of the downslope sliding of the entire massif of Etna (Murray et al. 2018). We create a mechanical analogue model set that incorporates the structural environment of Etna (its edifice, the substrata, and bounding mountains and coastal conditions) and follows the faults naturally generated by consequent combined gravity spreading and sliding. Using this series of laboratory analogue models, we successfully simulate all the major fault systems of Etna. We demonstrate why they are there, and how they interact with each other. This provides a structural system on which to place observations of deformation, and to frame eruption, landsliding and seismic hazards.

\section{The fault systems of Etna}

There are several major zones of faulting on Etna, illustrated in the map of Fig. 1. Either side of the summit are the north-south bounding faults of the cryptic summit graben. On the flanks, in clockwise order from the north, there are the Pernicana fault system, an arcuate left-lateral strikeslip fault running from the Northeast Rift, curving round towards the east, and then ESE towards the Mediterranean sea. Southeast of the Pernicana fault is the Ripa della Naca, a prominent step fault system running northeast from Citelli, downthrown towards the southeast. Running down the east flank of Etna is a series of normal faults trending about N10 W $\mathrm{W}$ to N-S, known as the Timpe system. At their south end one of them becomes the Acireale fault, a prominent coastal fault downthrown eastward into the Mediterranean sea. South of Etna are three prominent right-lateral strike-slip fault systems, the Trecastagni fault, the Mascalucia-Tremestieri fault, and the Gravina fault, the most southerly fault on Etna. On a similar alignment are the Tarderia faults, briefly exposed nearer the summit cone. Finally, much further west are the north-south right-lateral strike-slip Ragalna faults. 


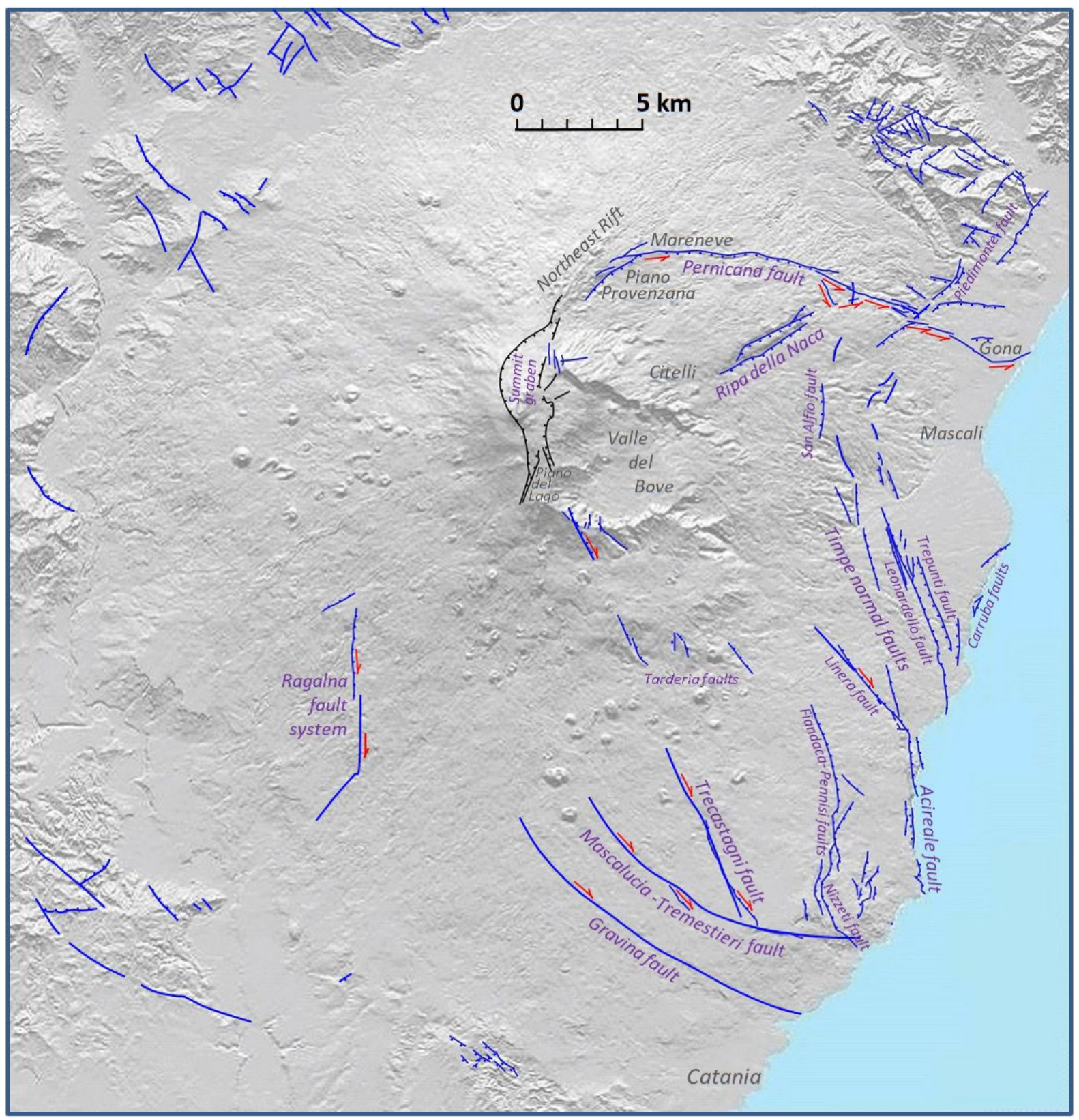

Fig. 1 Map of the faults of Mt Etna and its immediate surroundings, based on maps in Rust \& Neri 1996, Rasa et al. 1996, Monaco et al. 1997, Froger et al. 2001, Neri et al. 2004, Branca et al. 2011a, and Murray 2019. Blue lines are the faults, with ticks on the downthrow side, and black lines the bounding faults of the summit graben. Red arrows indicate the direction of strike-slip movement at transcurrent faults.

\subsection{Summit Graben}

The most active Etna faults, at least in terms of their cumulative movement, are those bounding the cryptic summit graben (Murray 2019). Mean annual rates of graben subsidence 1975-2018 vary from $88 \mathrm{~mm} \mathrm{y}^{-1}$ north of the summit to $61 \mathrm{~mm} \mathrm{y}^{-1}$ south of it. Extension across the graben is even greater, at $229 \mathrm{~mm} \mathrm{y}^{-1}$ (north) to $179 \mathrm{~mm} \mathrm{y}^{-1}$ (south of summit). Episodes of graben sinking and widening have been contemporary with flank eruptions, notably 1981, 1983, 1985, 1989, 1991-3, 2002-3 and 2008-9. In each case, sinking and extension accelerates rapidly at the start of the eruption, and then returns to slower rates over 1 to 3 years. This extension is magma-assisted as opening dykes force the rocks apart, creating slivers of uplift close to the dyke in a few cases. The 
93 greatest and most widespread sinking and extension occurred during the north-south bilateral

94 eruption of 2002-2003, when most measuring stations both north and south of the summit were

95 affected.

\section{$96 \quad 2.2$ The Pernicana Fault}

97 This is the most active of the Etna flank faults. It originates at the Northeast Rift, whose eastern side

98 is the site of a listric fault (well seen in the Piano Provenzana) kinematically connected to the Pernicana fault (Gropelli \& Tibaldi 1998). Near its proximal end, movements are clearly visible where the fault crosses roads. Serious cracking has been caused during local earthquakes on at least twelve occasions 1980-2020 south of Mareneve (Obrizzo et al. 2001, Bonaccorso et al. 2013) and smaller seismic events occur with monthly frequency (Lo Giudice \& Rasa 1992). The southerly dipslip component of this fault has been documented meticulously by repeated occupations of a precise levelling traverse installed in 1980 (Obrizzo et al. 2001). These show a total of $940 \mathrm{~mm}$ subsidence 1980-2019 of the southern side of the fault at this location, or a mean annual drop of $24 \mathrm{~mm} \mathrm{y}^{-1}$ (Murray 2019). The left-lateral strike-slip component is of a similar order, averaging about $26 \mathrm{~mm} \mathrm{y}^{-1}$ (Neri et al. 2004), though this can briefly accelerate up to $100 \mathrm{~mm} \mathrm{y}^{-1}$ following eruptions (Bonaccorso et al 2006, Bonforte 2008). The fault can be traced as far as the sea, in the displacement it has caused to walls, buildings and road edges (Tibaldi \& Gropelli 2002). The leftlateral movement remains about the same all along the fault, though sticking in some places more than others. Near the sea at Gona it has moved $1370 \mathrm{~mm}$ in about 70 years, or $20 \mathrm{~mm} \mathrm{y}^{-1}$ (Neri et al. 2004), and Garduño et al. (1997) find values of $26 \pm 5 \mathrm{~mm} \mathrm{y}^{-1}$ Since 1874. It has been continuing at these rates throughout the Holocene: matching up points on a cinder cone near Mareneve dated at 13,700 years B.P., Tibaldi \& Gropelli (2002) derive a strike-slip displacement of 370 metres, giving a mean value of $27 \pm 7 \mathrm{~mm} \mathrm{y}^{-1}$.

\subsection{The Ripa della Naca and nearby faults of similar orientation}

Marked by a prominent southeast-facing fault scarp over $100 \mathrm{~m}$ high, the Ripa della Naca has been inactive for the past 15,000 years (Tibaldi \& Gropelli 2002). Nevertheless, the Ripa della Naca faults played a critical part in the 1928 eruption, creating a preferential pathway for magma that erupted above the town of Mascali, completely destroying it in less than a week (Branca et al. 2017).

In a similar orientation, but $5 \mathrm{~km}$ east, lies the Piedimonte fault, also downthrown southeastward. This fault is active, with vertical slip rates of 1 to $2 \mathrm{~mm} \mathrm{y}^{-1}$ throughout the past $500 \mathrm{kyr}$, (Monaco et al 1997, Tibaldi \& Gropelli 2002), and it cuts across the Pernicana fault. The Carruba faults also share the same orientation, but are $12 \mathrm{~km}$ southeast of the Ripa della Naca, by the sea.

\subsection{The Timpe fault systems}

"Timpe" (singular: "timpa"), is a local name for the prominent seaward-facing fault scarps down the lower east flanks of Etna. They are oriented between north-south and northwest-southeast, and whilst most are normal faults downfaulted towards the east, there are also some downthrown west, including the San Alfio fault (Fig 1), the most northerly, which has had vertical slip velocities 1 to 2 $\mathrm{mm} \mathrm{y}^{-1}$ over the past 80,000 years (Monaco et al 1997), and extension a fraction of this. In places the westward and eastward-facing faults form graben and horsts. They include the parallel Trepunti and Leonardello faults which together form a $5 \mathrm{~km}$ graben. The most westerly Timpe fault, the 
Linera fault, is oriented $\mathrm{N} 40^{\circ} \mathrm{W}$, and has a slight right-lateral component of movement. At its southern end it runs into the Acireale fault, which forms a prominent north-south cliff 50-100 $\mathrm{m}$ high for $7 \mathrm{~km}$ down the coastline. Most of these faults are associated with shallow seismicity, and have had vertical slip rates of between 1 and $2 \mathrm{~mm} \mathrm{y}^{-1}$ over the past 1 to $168 \mathrm{kyr}$ (Monaco et al 1997). Like the Pernicana fault, much higher rates are possible over short time periods: Azzaro et al (2020) recorded over $100 \mathrm{~mm}$ of vertical displacement at the San Leonardello fault associated with seismic and creep events in 2009 and 2016. The Timpe fault system probably relates to the instability of the submarine margin (e.g. Argani et al 2013, Chiocci et al 2011, Gross et al 2016, Azzarro et al 2020).

\subsection{The Mascalucia-Tremestieri, Trecastagni \& Gravina fault systems}

There are at least three transcurrent faults, all with right-lateral slip, that make up a southern boundary to the sector of eastward movement of the east flank of Etna. In this way they correspond to the Pernicana fault in the north, though since the strain release is taken up by 3 faults, they are individually less active than the Pernicana fault, with smaller annual rates of displacement. The Mascalucia-Tremestieri fault is at least $12 \mathrm{~km}$ long, and has a similar radius of curvature to the Pernicana fault, though curving northwards rather than southward. Gross et al (2016), using High resolution 2D seismic data, demonstrate that a prolongation of this fault extends a further $12 \mathrm{~km}$ eastward beyond the shoreline. The Gravina fault is the most southerly of the Etna faults, lying parallel to the Mascalucia-Tremestieri fault but about $3 \mathrm{~km}$ south of it.

The Fiandaca-Pennisi faults, which form part of the Timpe system in its northern part, intertwine with the Nizzeti fault at its southern end. The Nizzeti fault joins the Mascalucia-Tremestieri fault close to the Mediterranean shore, curving round southeastwards as it does so. The Trecastagni fault is also similar to the Timpe system in orientation, running about $\mathrm{N} 20^{\circ} \mathrm{W}$, but has a right-lateral motion, and runs into the Mascalucia-Tremestieri fault at its southern end. Its northwestern end possibly continues into the western Tarderia fault, and perhaps even further into the right-lateral strike-slip dry fissure on the outer southern slope of the Valle del Bove that accompanied the start of the 1989 eruption (Ferrucci et al 1993). The central and eastern Tarderia faults may perhaps connect with other faults in the outer southern Valle del Bove wall, and may extend further south into the area between the Fiandaca-Pennisi Faults and Trecastagni faults, but possible exposures are covered by the 1792-3 and 1634-6 flows in the north, and by flows of medieval age to the south.

The creep of this system of southern faults was followed seismically in the 1980s by Lo Giudice \& Rasa (1992) and in the 1990s using radar interferometry by Froger et al (2001) and Ranvier (2004), also by Urlaub et al (2018) in 2016-2017. Phases of creep and seismicity lasting up to 16 months were observed. The radar interferograms show clearly that both the Mascalucia-Tremestieri and Gravina Faults extend further northwest than was previously suspected from geological exposures, the former connecting to the southern rift zone of the volcano, strengthening its correspondence to the Pernicana fault in the north. Velocities of right-lateral creep 1993-1997 were of the order of 15 $\mathrm{mm} \mathrm{y}^{-1}$ for the Gravina fault, $10 \mathrm{~mm} \mathrm{y}^{-1}$ for the Mascalucia-Tremestieri fault, and $5 \mathrm{~mm} \mathrm{y}^{-1}$ for the Trecastagni fault (read from Ranvier 2004 interferogram map). Similar values were found by Solaro et al. (2010), and Bonforte et al (2011), analysing a range of interferograms 1995-2000, derived annual right-lateral displacements of $5 \mathrm{~mm} \mathrm{y}^{-1}$ for the Gravina fault, and $15 \mathrm{~mm} \mathrm{y}^{-1}$ for the Mascalucia-Tremestieri fault, at a time when the Pernicana fault showed stronger left lateral displacement of $25 \mathrm{~mm} \mathrm{y}^{-1}$. As with other faults, much higher rates are possible during single events: 
in May 2017, $40 \mathrm{~mm}$ right-lateral slip in 8 days was measured across the seaward extension of the Mascalucia-Tremestieri fault (Urlaub et al. 2018).

\subsection{Ragalna faults}

These are the furthest southeast of any of the active Etna fault systems. The main faults are downthrown on the east side, with long term dip-slip movement of up to $1.4 \mathrm{~mm} \mathrm{y}^{-1}$, and are the site of periodic earthquakes and aftershocks, as in 1977-78 (Cristofolini et al 1981), and 1991 (Ferruci \& Patane 1993). Both these events gave fault-plane solutions revealing right-lateral displacement.

Rust \& Neri (1996) and Neri et al (2007) argue that the Ragalna faults mark the western boundary of the unstable eastern sector of the volcano, corresponding to the Pernicana fault system in the northeast. If this is the case, it places the western boundary $12 \mathrm{~km}$ further west than the Mascalucia-Tremestieri/Gravina fault systems favoured by previous workers.

\section{Laboratory analogue modelling}

We have created analogue models of the fault systems described above in the laboratory, following the same methodology as the experiments originally carried out by Merle \& Borgia (1996) which have now become standard practice in studies of this kind (Merle \& Lénat 2003, Wooller et al. 2004). In most previous studies, the approach has been to make models of general cases. The approach differs here, in that we aim to model a specific case, by scaling the main material properties and topographic features of Etna, and then observing the resulting structures produced and their evolution. Our model setup, designed to achieve this specific case is shown in Figs 2 and 3.

\subsection{Model configurations}

The sub-volcanic basement on which Etna lies is represented by a layer of silicon putty, a ductile material that slowly flows (Merle \& Borgia 1996) until its surface becomes level, which happens after about 12 hours under ambient conditions. The putty is placed on a flat board on a bench, and left to find its own level. To stop the putty flowing off the board, in most experiments a rampart of sand is placed all around the edges, which in some places will later also represent the mountains around Etna. The model is then left overnight, by which time the putty has formed a lake surrounded by sand ramparts. Next, a layer of sand is placed over the putty layer. Its surface is levelled by dragging a long straight edge across the top of the sand layer, the straight edge being supported by horizontal guides either side of the model to keep it level. This layer of sand, which behaves as a brittle material, represents the extensive apron of lavas that surround the summit cone of Etna below about $2000 \mathrm{~m}$.

The summit of Etna is represented by a sand cone, placed off-centre to the north as on Etna, and the entire model is sprinkled with plaster powder, to make surface fractures visible, and dusted with pepper to provide identifiable reference points for measurement. The model is then tilted slightly to the right, to represent the sloping basement of Etna, and the sand at the bottom of the slope removed, to represent the unbuttressed Mediterranean side of Etna. Some surrounding sand is also removed from the top right edge, corresponding to where the Peloritan Mountains end, and in some 
213

214

215

experiments along the bottom right edge, to represent the end of the low range of hills south of Etna.

The model starts to visibly deform and change shape after a few minutes, and surface cracks appear after 15 to 20 minutes. These develop into faults and graben which become more pronounced and numerous as the experiment progresses. The experiment is usually stopped after an hour or so, though occasionally it is left to run for two or three hours.
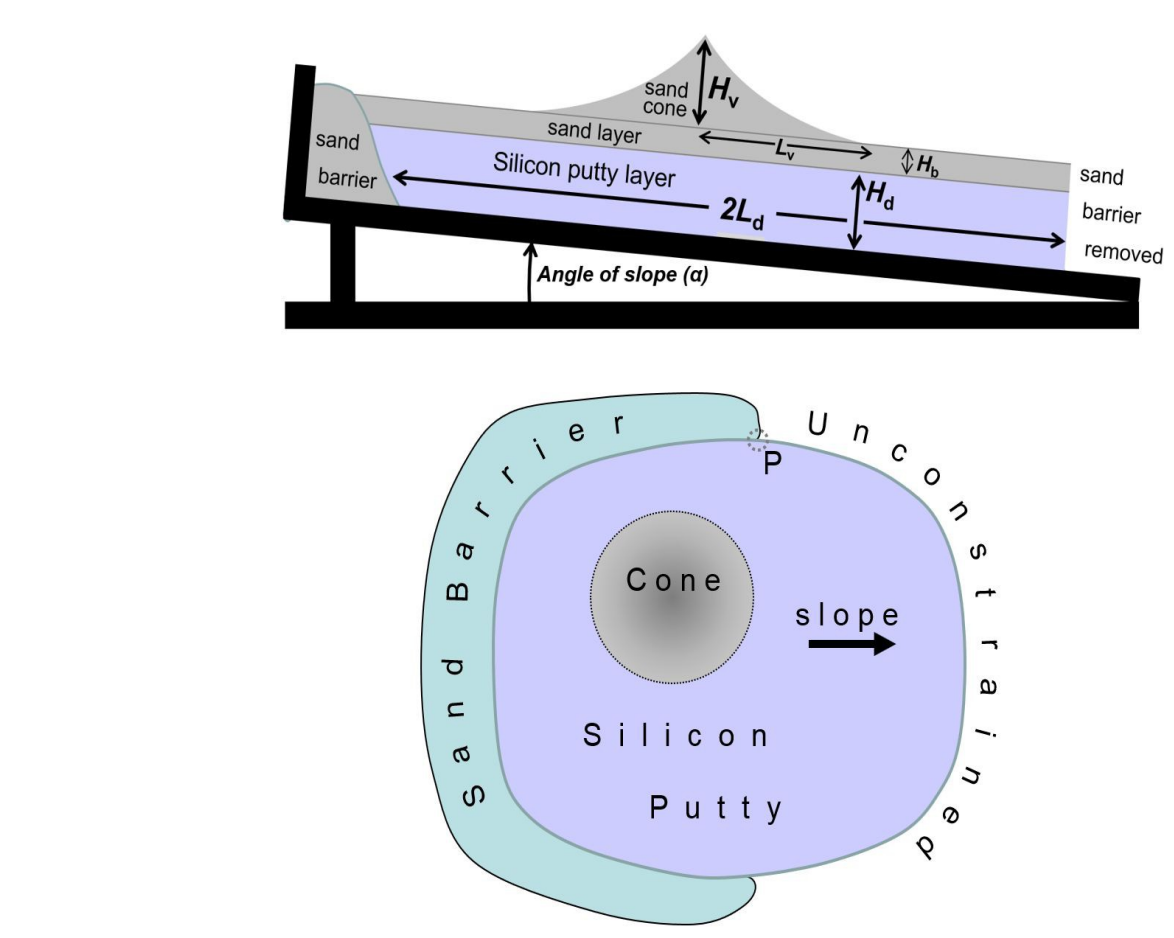

Fig.2. Top: Cross section of the experimental setup for the analogue modelling. Bottom: plan view. Dimensions and material properties are matched to those of Etna. See text and Tables I and II for details. 
Non-peer reviewed preprint submitted to Journal of Volcanology \& Geothermal Research

234 Table I Values for the geometric variables and material properties (defined below in Section 3.2) in

235 nature and the analogue laboratory experiments.

$\begin{array}{lllll}236 & \text { Variable } & \text { Units } & \text { Etna } & \text { Laboratory } \\ 237 & H_{v} & \mathrm{~m} & 1100-1600 & 0.027-0.060 \\ 238 & L_{v} & \mathrm{~m} & 3200-6000 & 0.046-0.089 \\ 239 & H_{b} & \mathrm{~m} & 200-900 & 0.01-0.02 \\ 240 & H_{d} & \mathrm{~m} & >89 & 0.009-0.025 \\ 241 & L_{d} & \mathrm{~m} & >32,000 & 0.11-0.27 \\ 242 & \alpha & \text { degrees } & 0^{\circ}-4^{\circ} & 0^{\circ}-2^{\circ} .7 \\ 243 & \rho_{v} & \mathrm{~kg} \mathrm{~m}^{-3} & 2500 & 1400 \\ 244 & \rho_{b} & \mathrm{~kg} \mathrm{~m}^{-3} & 2500 & 1400 \\ 245 & \rho_{d} & \mathrm{~kg} \mathrm{~m}^{-3} & 1900 & 1000 \\ 246 & \Phi & \text { degrees } & 35^{\circ} & 35^{\circ} \\ 247 & \mu_{d} & \text { Pa s} & 10^{19} & 2 \times 10^{5} \\ 248 & g & \mathrm{~m} \mathrm{~s}^{-2} & 9.81 & 9.81 \\ 249 & T & \mathrm{~S} & 10^{12} & 2.1 \times 10^{3}-11.76 \times 10^{3}\end{array}$




\subsection{Scaling Analysis}

The parameters used in the scaling analysis are illustrated in fig. 2 . The relative dimensions and position of the cone, thickness of the sand and silicon putty layers etc. are chosen to match those of Etna, and varied in the different models where a range of values exist, or if values are only known within given limits. Table I gives a list of geometric variables and material properties for the principal parameters of Etna, as far as these are known, and the model. Geometric variables include the sand cone height $\left(H_{v}\right)$ and radius $\left(L_{v}\right)$, the thickness of the sand layer $\left(H_{b}\right)$ and silicon putty layer $\left(H_{d}\right)$, the radius of the silicon putty layer $\left(L_{d}\right)$ and the angle of substrate dip $(\alpha)$. Material properties include the densities of the sand cone $\left(\rho_{v}\right)$, the sand layer $\left(\rho_{b}\right)$ and the silicon putty layer $\left(\rho_{d}\right)$, the angle of internal friction of the sand $(\Phi)$, and the viscosity of the silicon putty $\left(\mu_{d}\right)$. The force of gravity $(g)$ is included, and the time span of deformation $(T)$. The scaling method of Merle and Borgia (1996) is used, but with an extra term for substratum slope introduced by Wooller et al. (2004). The laboratory variables scale up to those on Mt. Etna within the uncertainty of the latter values. Etna values for $H_{b}$ and $H_{d}$ are derived from Branca and Ferrara (2013); other properties from Wooller et al. (2004) and Merle and Borgia (1996).

\subsection{Laboratory Experiments}

Altogether, 14 laboratory experiments were carried out, each one using slightly different values for the thickness of the layers of sand and silicon putty, the summit cone height and shape, the slope angle of the basement, the angle of the spreading sector, and the position of the summit cone. The top part of Table II shows details of each experiment.

The sand layer and the Silicon putty layer are varied in thickness, because the apron of lavas and the layer of ductile sediments beneath Etna also vary in thickness (Branca \& Ferrara 2013). Different values for the summit cone height and base width reflect the varying height of Etna's summit over the past 300 years, and the north-south elongation of Etna's summit cone. The slope of the basement also varies from around $0^{\circ}$ beneath the northwest flank to $4^{\circ}$ in parts of the eastern flanks. The time for Etna to deform is fixed at $10^{12}$ seconds, or just over 30,000 years. This is a time period long enough for all major structures to form at the observed natural displacement rates, and is a time period over which Etna has largely maintained its present position and shape (Branca et al 2011b, De Beni et al. 2011).

The sand cone was circular in most experiments, as this was easiest to standardise by pouring sand through a funnel, but in 3 experiments the cone was roughly elongated (e.g. Fig. 3). The placement of the cone on the sand layer was critical to the formation of some of the fracture fields, and is listed in table II as N-S eccentricity and E-W eccentricity. A range of values was tried in each case, including dead central for experiment 1. 
Table II (Top) Values for the geometric variables in each of the 14 analogue laboratory experiments. (Bottom) Results of each of the 14 experiments. A tick $(\sqrt{ })$ indicates that a feature resembling the fault is present in the model, a query (?) means that a similar feature is present but slightly different from the fault on Etna. Numbers of fault systems definitely present in each model are given at the bottom, and as a percentage of all the Etna fault systems named in Fig. 1. Numbers of experiments which contained each of the Etna fault systems are given in the columns to the right, with percentages of the total number of experiments also.

\begin{tabular}{|c|c|c|c|c|c|c|c|c|c|c|c|c|c|c|c|c|}
\hline Experiment No: & 1 & 2 & 3 & 4 & 5 & 6 & 7 & 8 & 9 & 10 & 11 & 12 & 13 & 14 & MEANS & \\
\hline \multirow{2}{*}{$\begin{array}{r}\text { Duration (minutes) } \\
\text { Silicon putty thickness } \mathrm{mm}\end{array}$} & 79 & 57 & 133 & 81 & 133 & 121 & 196 & 111 & 79 & 75 & 51 & 60 & 65 & 35 & 91 & minutes \\
\hline & 14 & 21.5 & 25 & 14 & 21 & 21 & 14 & 11 & 9 & 9 & 14 & 12 & 16 & 21 & 16 & $m m$ \\
\hline Sand apron thickness $\mathrm{mm}$ & 12 & 20 & 12 & 12 & 15 & 20 & 10 & 10 & 15 & $11-5$ & 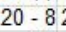 & $20-8$ & $20-0$ & 20 & 14 & $m m$ \\
\hline Cone height $\mathrm{mm}$ & 27 & 45 & 27 & 27 & 34 & 45 & 60 & 45 & 45 & 45 & 45 & 45 & 45 & 45 & 41 & $m m$ \\
\hline Cone base width $\mathrm{mm}$ & 97 & 95 & 106 & 91 & 92 & 161 & 170 & 150 & 159 & 162 & 178 & 150 & 140 & 154 & 136 & $m m$ \\
\hline \multirow{2}{*}{$\begin{array}{l}\text { Flared cone? } \\
\text { Elongate cone }\end{array}$} & no & yes & no & yes & no & yes & yes & yes & yes & yes & yes & yes & yes & yes & & \\
\hline & no & no & no & no & no & no & no & no & no & yes & yes & no & no & yes & & \\
\hline Basement slope & $2^{\circ}$ & $\left(4^{\circ}\right)$ & $1^{\circ}$ & $2^{\circ}$ & $2^{\circ}$ & $2^{\circ}$ & $2^{\circ}$ & $2^{\circ}$ & $2^{\circ}$ & $2^{\circ} .7$ & $2^{\circ}$ & $2^{\circ}$ & $2^{\circ}$ & $2^{\circ} .6$ & 1.9 & \\
\hline \multirow{2}{*}{$\begin{array}{l}N-S \text { eccentricity }\{\text { central }=0 \\
E-W \text { eccentricity }\{\text { edge }=100\end{array}$} & 0 & 39 & 33 & 23 & 13 & 39 & 25 & 30 & 22 & 23 & 47 & 24 & 42 & 24 & 27 & \\
\hline & 0 & 22 & 18 & 0 & 16 & 47 & 33 & 35 & 30 & 33 & 54 & 60 & 39 & 4 & 28 & \\
\hline \multirow{2}{*}{$\begin{array}{r}\text { Basement } \mathrm{N}-\mathrm{S} \mathrm{mm} \\
\text { Basement } \mathrm{E}-\mathrm{W} \mathrm{mm}\end{array}$} & 270 & 613 & 350 & 280 & 300 & 260 & 480 & 370 & 460 & 470 & 340 & 380 & 380 & 280 & 374 & $m m$ \\
\hline & 270 & 380 & 380 & 280 & 380 & 300 & 480 & 400 & 540 & 540 & 390 & 450 & 330 & 220 & 381 & $\mathrm{~mm}$ \\
\hline Notes & & $\begin{array}{l}\text { slope } \\
\text { in one } \\
\text { step }\end{array}$ & $\begin{array}{l}\text { south } \\
\text { edge } \\
\text { free }\end{array}$ & & & & $\begin{array}{l}\text { base } \\
\text { is } 7 \mathrm{~mm} \\
E-W \\
\text { valley }\end{array}$ & $\begin{array}{l}\text { slope } \\
\text { steep- } \\
\text { ens to } \\
\text { east }\end{array}$ & & $\begin{array}{l}\text { sand } \\
\text { layer } \\
\text { thins } \\
\text { to } \mathrm{E}\end{array}$ & $\begin{array}{l}\text { sand } \\
\text { layer } \\
\text { thins } \\
\text { to } E\end{array}$ & $\begin{array}{l}\text { sand } \\
\text { layer } \\
\text { thins } \\
\text { to SE }\end{array}$ & $\begin{array}{l}\text { sand } \\
\text { layer } \\
\text { thins } \\
\text { to SE }\end{array}$ & $\begin{array}{l}\text { "V.d.B." } \\
\text { scooped } \\
\text { out after } \\
30 \mathrm{~m}\end{array}$ & & \\
\hline
\end{tabular}

ETNA FAULTS REPRESENTED IN THE ABOVE MODELS:

\begin{tabular}{|c|c|c|c|c|c|c|c|c|c|c|c|c|c|c|c|c|c|c|}
\hline & & & & & & & & & & & & & & & & & & \\
\hline Summit graben width: & 0.31 & 0.30 & & 0.38 & 0.38 & 0.28 & 0.30 & 0.24 & 0.28 & 0.20 & 0.28 & 0.38 & 0.30 & 0.22 & & & 0.30 & \\
\hline & & & & & & & & & & & \multicolumn{2}{|c|}{ (2 graben) } & & & & & & \\
\hline Summit graben & $\sqrt{ }$ & $\sqrt{ }$ & $?$ & $?$ & $\sqrt{ }$ & $\sqrt{ }$ & $\sqrt{ }$ & $\sqrt{ }$ & $\sqrt{ }$ & $\sqrt{ }$ & $\sqrt{ }$ & $\sqrt{ }$ & $\sqrt{ }$ & $\sqrt{ }$ & 12 & $86 \%$ & \multicolumn{2}{|c|}{ Summit graben } \\
\hline Pernicana fault & $\sqrt{ }$ & $?$ & $?$ & $?$ & $\sqrt{ }$ & $\sqrt{ }$ & $\sqrt{ }$ & $\sqrt{ }$ & $\sqrt{ }$ & $\sqrt{ }$ & $\sqrt{ }$ & $\sqrt{ }$ & $\sqrt{ }$ & $\sqrt{ }$ & 11 & $79 \%$ & \multicolumn{2}{|c|}{ Pernicana fault } \\
\hline Piedimonte fault & & & $?$ & & $?$ & $\sqrt{ }$ & & & $\sqrt{ }$ & & $\sqrt{ }$ & & $\sqrt{ }$ & $\sqrt{ }$ & 5 & $36 \%$ & \multicolumn{2}{|c|}{ Piedimonte fault } \\
\hline Ripa della Naca & $?$ & $\sqrt{ }$ & $\sqrt{ }$ & & $\sqrt{ }$ & $\sqrt{ }$ & $\sqrt{ }$ & $\sqrt{ }$ & $\sqrt{ }$ & $\sqrt{ }$ & $\sqrt{ }$ & $\sqrt{ }$ & $\sqrt{ }$ & $\sqrt{ }$ & 12 & $86 \%$ & \multicolumn{2}{|c|}{ Ripa della Naca } \\
\hline Trepunti fault & & $\sqrt{ }$ & $\sqrt{ }$ & & $\sqrt{ }$ & $\sqrt{ }$ & $\sqrt{ }$ & $\sqrt{ }$ & & & & & $?$ & $\sqrt{ }$ & 7 & $50 \%$ & \multicolumn{2}{|c|}{ Trepunti fault } \\
\hline Leonardello fault & & $\sqrt{ }$ & $\sqrt{ }$ & & $\sqrt{ }$ & $\sqrt{ }$ & $\sqrt{ }$ & $\sqrt{ }$ & & & & & $?$ & $\sqrt{ }$ & 7 & $50 \%$ & \multicolumn{2}{|c|}{ Leonardello fault } \\
\hline Acireale fault & $?$ & $?$ & & & & $\sqrt{ }$ & $\sqrt{ }$ & $\sqrt{ }$ & & & $?$ & $?$ & $\sqrt{ }$ & & 4 & $29 \%$ & \multicolumn{2}{|c|}{ Acireale fault } \\
\hline Nizzeti faults & & & $?$ & $\sqrt{ }$ & $?$ & $?$ & $\sqrt{ }$ & $\sqrt{ }$ & & & & & $?$ & & 3 & $21 \%$ & \multicolumn{2}{|c|}{ Nizzeti faults } \\
\hline Trecastagni fault & & & $\sqrt{ }$ & & $\sqrt{ }$ & $\sqrt{ }$ & $\sqrt{ }$ & $\sqrt{ }$ & $\sqrt{ }$ & & $\sqrt{ }$ & & $\sqrt{ }$ & & 8 & $57 \%$ & \multicolumn{2}{|c|}{ Trecastagni fault } \\
\hline Mascalucia-Tremestieri fault & $\sqrt{ }$ & & $?$ & & $\sqrt{ }$ & $\sqrt{ }$ & $\sqrt{ }$ & $\sqrt{ }$ & $\sqrt{ }$ & & $\sqrt{ }$ & & & & 7 & $50 \%$ & \multicolumn{2}{|c|}{ - Mascalucia-Tremestieri fault } \\
\hline \begin{tabular}{|l|l} 
& Tarderia fault \\
\end{tabular} & $\sqrt{ }$ & $\sqrt{ }$ & $\sqrt{ }$ & $\sqrt{ }$ & $?$ & $\sqrt{ }$ & $\sqrt{ }$ & $\sqrt{ }$ & $\sqrt{ }$ & $\sqrt{ }$ & $\sqrt{ }$ & $\sqrt{ }$ & $\sqrt{ }$ & $\sqrt{ }$ & 13 & $93 \%$ & \multicolumn{2}{|c|}{ Tarderia fault } \\
\hline Ragalna fault system & $\sqrt{ }$ & $\sqrt{ }$ & $\sqrt{ }$ & $\sqrt{ }$ & $\sqrt{ }$ & $\sqrt{ }$ & $\sqrt{ }$ & $\sqrt{ }$ & $\sqrt{ }$ & & $\sqrt{ }$ & & $\sqrt{ }$ & $\sqrt{ }$ & 11 & $79 \%$ & \multicolumn{2}{|c|}{ Ragalna fault system } \\
\hline \begin{tabular}{|l|l} 
& Carruba faults \\
\end{tabular} & $\sqrt{ }$ & & $\sqrt{ }$ & & & & $\sqrt{ }$ & $?$ & & & $\sqrt{ }$ & $\sqrt{ }$ & & $\sqrt{ }$ & 6 & $43 \%$ & \multicolumn{2}{|c|}{ Carruba faults } \\
\hline San Alfio fault & $\sqrt{ }$ & $\sqrt{ }$ & $\sqrt{ }$ & $\sqrt{ }$ & $\sqrt{ }$ & $\sqrt{ }$ & $\sqrt{ }$ & $\sqrt{ }$ & & & & & $\sqrt{ }$ & $?$ & 9 & $64 \%$ & \multicolumn{2}{|c|}{ San Alfio fault } \\
\hline Linera fault & & & $\sqrt{ }$ & & & $\sqrt{ }$ & $\sqrt{ }$ & & $\sqrt{ }$ & & & & $\sqrt{ }$ & $\sqrt{ }$ & 6 & $43 \%$ & \multicolumn{2}{|c|}{ Linera fault } \\
\hline Gravina fault & $\sqrt{ }$ & & & & & & $\sqrt{ }$ & $\sqrt{ }$ & & & $\sqrt{ }$ & & & & 4 & $29 \%$ & \multicolumn{2}{|c|}{ Gravina fault } \\
\hline TOTALS (certain): & 8 & 7 & 9 & 4 & 9 & 13 & 15 & 13 & 9 & 4 & 10 & 5 & 10 & 10 & & $56 \%$ & & \\
\hline$\%$ Etna faults in model: & $50 \%$ & $44 \%$ & $56 \%$ & $25 \%$ & $56 \%$ & $81 \%$ & $94 \%$ & $81 \%$ & $56 \%$ & $25 \%$ & $63 \%$ & $31 \%$ & $63 \%$ & $63 \%$ & & $56 \%$ & & \\
\hline
\end{tabular}

\section{Results}

Table II (bottom) shows the results of each experiment. Ticks indicate the fault system is present in the experiment. A question mark is given if the faults had a noticeably different orientation, or were weak or more pronounced or more extensive than on Etna. All the faults named in Fig. 1 appeared in at least 4 of the 14 simulations, and faults corresponding to the summit graben, Pernicana fault, Ripa della Naca, Tarderia faults and the Ragalna fault were present in 11 or more of the 14 simulations. The width of the summit graben in each model is given at the top, as a fraction of the summit cone width. Fig. 3 illustrates experiment 11, both at the start, and after running for 50 minutes, when many analogues of the above faults are visible. It should be noted that the faults ticked in Table II were not necessarily visible at every stage of the experiment: some changed character or were obscured by later fault development. Fig. 5 (middle row) shows experiment 7 
after 43 minutes, and also after 237 minutes. New faults have appeared, straight faults have become curved, and fault movement has increased at some faults, and decreased at others.
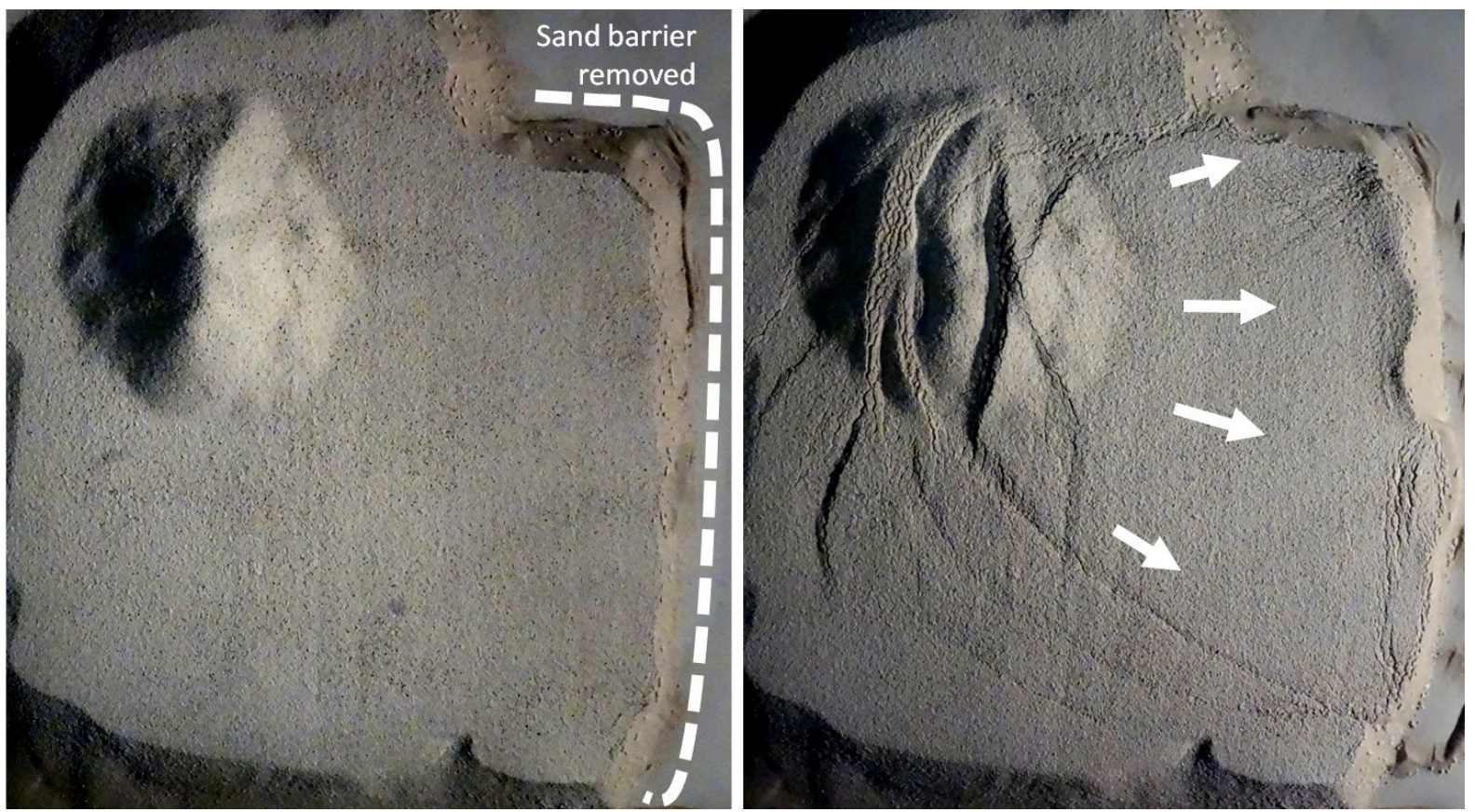

Fig. 3. Experiment No. 11 (left) at the start, and (right) after running for 50 minutes. Slope of the base is $2^{\circ}$ to the right. In this experiment, an attempt has been made to represent the north-south elongation of the summit cone of Etna, with the Northeast Rift. The dashed line down the right side of the left image shows where the sand barrier has just been removed, creating an unconstrained lower edge. After 50 minutes, the underlying ductile silicon putty has spread towards the unconstrained sector (arrows), carrying the right side of the sand cone and apron with it, creating a north-south summit graben and fault patterns similar to those of Etna.

\subsection{Model to Etna fault correspondence}

We now examine each of the fault systems appearing in the models, and how these correspond to what actually happens on Etna. For convenience, the direction of downwards slope toward the right edge of each model is referred to as east, and the other edges accordingly, even though the direction of basement slope on Etna is closer to east-southeast.

\subsubsection{Summit graben}

Figs 3 and 4 show well-defined north-south summit graben in every experiment. This is usually the first feature to develop, and becomes wider and more pronounced as the experiment progresses. These graben are the result of two processes operating in every model. The stresses within a gravitationally spreading sand cone inevitably result in the formation of leaf graben (Merle \& Borgia 1996). At the same time, downslope sliding increases tensional stress in the east-west direction, thus augmenting the formation of leaf graben oriented north-south, but suppressing those oriented east-west. There is an interplay between these two processes, so if gravitational spreading dominates then leaf graben can form in other directions than north-south. In experiments 12 and 13 (Figs. 4 bottom right and 5 top left), an attempt was made to represent the thinning of the lava apron towards the sea by thinning the sand apron from $20 \mathrm{~mm}$ beneath the sand cone to $8 \mathrm{~mm}$ and 0 $\mathrm{mm}$ respectively at the eastern unconstrained edge. This differential load on the silicon putty 
beneath the cone has meant that spreading of the cone is relatively greater in these models, producing leaf graben oriented $10^{\circ}$ to $30^{\circ}$ from the north-south graben (model 12 ), and at around $50^{\circ}, 120^{\circ}$ and $150^{\circ}$ in model 13 . Some of the bounding faults of these graben are at similar positions and orientations to fractures formed during the 1983, 1985, 1989, 1991-3 and 2001 flank eruptions.

\subsubsection{Pernicana Fault system}

A fault starting at the northern end of the summit graben is present in most models, usually departing northeastwards and curving round to the east. This fault marks the boundary between restraining stresses caused by the topography to the north and the unrestrained eastern sector. Gravitational spreading of the sand cone northwards is obstructed by the presence of the sand ramparts representing the Peloritani mountains. This obstruction creates a relatively stable area to the left of point $P$ in Fig. 2 (bottom). However, to the right of point $P$ there is no such obstruction, so the cone can continue to spread freely in this direction. The dichotomy between these conflicting stresses is resolved in the formation of a left-lateral strike-slip fault, corresponding to the Pernicana fault.

Fig. 4 shows the regions north of the sand cone in three of the experiments listed in Table II. Analogues of the Pernicana fault, marked $P$ at each end, are visible in all of them. In each case at the lower left end they merge into the summit graben bounding faults (marked $g$ ) and terminate distally at the top edge of the model at the point where the sand rampart obstructing the putty has been removed. Experiment 9 has a single well-defined straight fault, whereas experiment 13 has a curving broad area of en échelon fissuring indicating left-lateral movement, and a parallel fault system at the northwest foot of the sand cone. Experiments 6 and 13 have additional parallel faults, some of them close to the eruptive fissure positions of 1947 and 2002. 

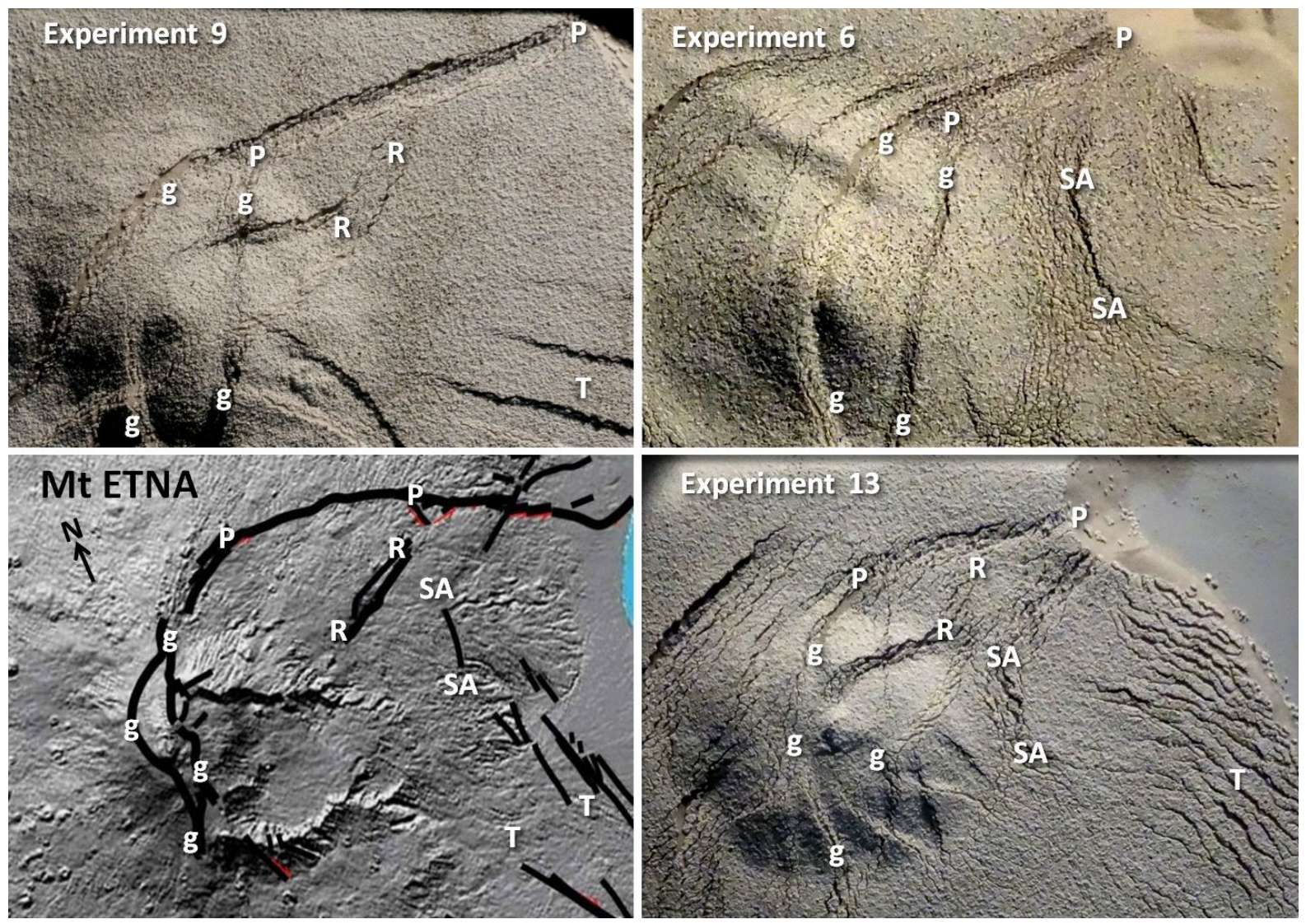

Fig. 4. Regions to the northeast of the sand cone in three experiments, with lighting from the east or northeast, together with a map of faults in the equivalent region of Mt Etna (lower left), rotated so that the downslope direction matches that of the models. The Pernicana fault is marked P P, the Ripa della Naca R R, the San Alfio fault SA SA, Timpe faults $T$ and the summit graben bounding faults $g \mathrm{~g}$, and analogues of these faults in the various experiments are similarly labelled. See text for details.

\subsubsection{Ripa della Naca and San Alfio faults}

Faults resembling the Ripa della Naca are seen in models 9 and 13 (Fig. 4), though in both cases they are small compared to the prominent fault scarp on Etna. They appear to have formed in response to the accumulating tensional stress as the silicon putty spreads downslope. West dipping faults aligned north-south appear further east in experiments 6 and 13 marked SA in Fig. 4. They appear to be transpressional, at least in experiment 6 , and are close to the San Alfio fault in position, orientation and dip direction. They lie at the downslope foot of the sand cone, where slope-assisted gravitational spreading comes against the slower-moving sand apron.

\subsubsection{Timpe faults}

In most experiments, as soon as the sand barrier is removed from the downslope edge of the model and the silicon putty starts to flow and spread out down this unconstrained slope, northwestsoutheast tensional cracks start to appear at the east edge in similar orientation and position to Timpe faults such as Trepunti, Leonardello and Linera, although these model faults are much more numerous in most experiments than on Etna. They are marked T in Fig. 4, experiments 9 and 13. The orientation of the model Timpe faults further west seem to be particularly sensitive to small relative changes in tensional stresses caused by downslope flow of the silicon putty, and those caused by spreading following the removal of sand from the northeast and southeast edges. For 
example, in some models where longer sections of the north and south sand barriers are removed, almost east-west cracks and graben develop (marked T in experiment 9, Fig. 4)..

North-south faults corresponding to the Acireale fault have developed the lower right edge of experiments in Fig. 5, where they are marked A. As on Etna, these model faults show a primarily extensional motion, without a strike-slip component in most cases.
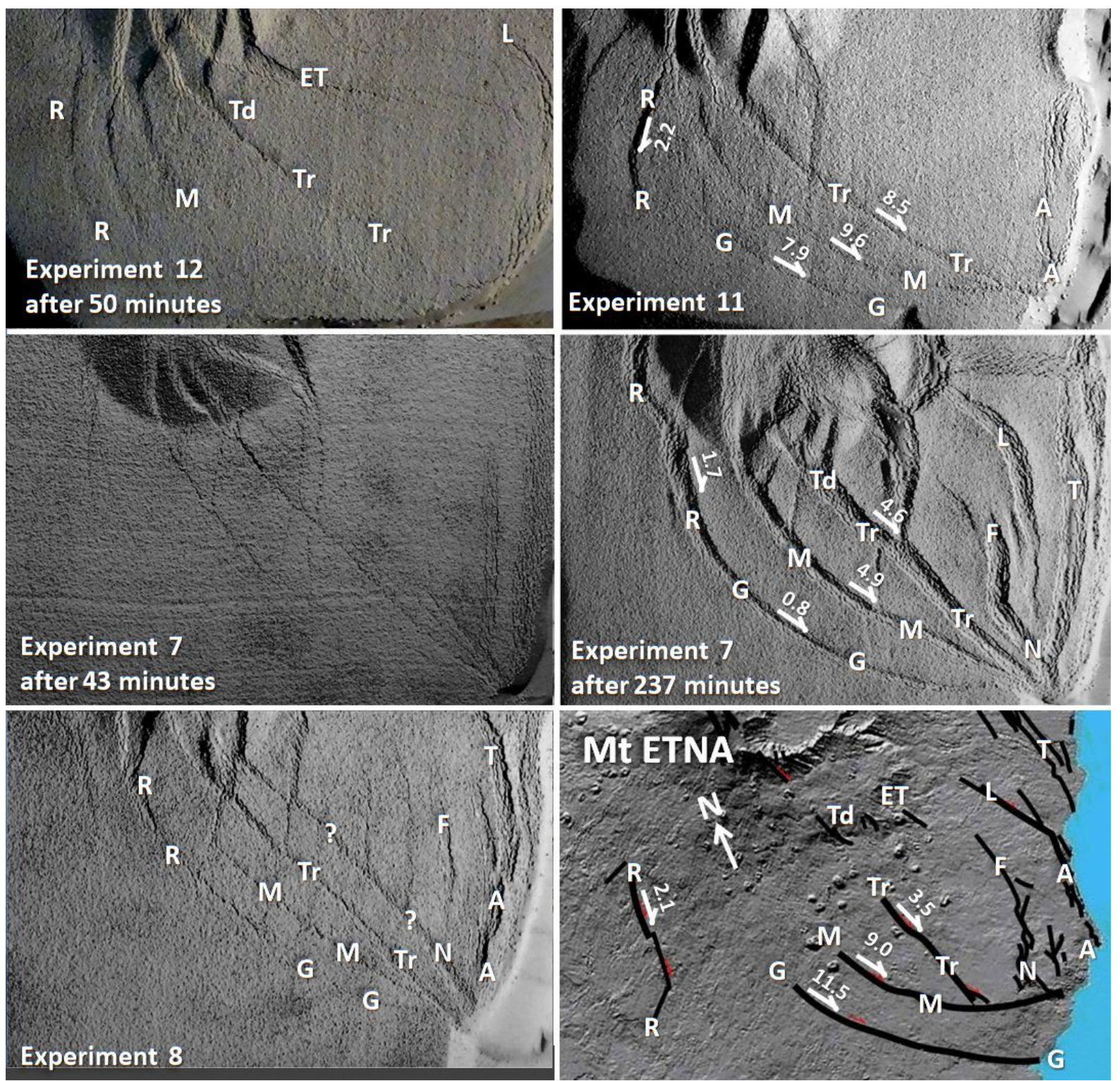

Fig. 5. Fault formation in the southeastern sector of four of the experiments listed in Table II, plus a map of faults on Mt Etna in the equivalent location (bottom right), rotated so that the downslope direction matches that of the experiments. Basement slope of the models is $2^{\circ}$ to the right (east), and lighting from the east or south. Prominent strike-slip faults are marked with their slip direction and annual rate of slip in $\mathrm{mm} \mathrm{y}^{-1}$, having been scaled as described in the text. Field measurements of strike-slip rates at the equivalent Etna faults are shown in the map bottom right. Experiment 7 is shown at two stages 194 minutes apart, and many changes in fault configurations are visible. Faults south of the sand cone have become more curved, and right-lateral strike-slip movement is evident in many places. New tensional faults have also appeared southeast of the sand cone. As in Fig. 4, the faults are labelled with their Etna equivalents, A A referring to the Acireale fault, ET to the eastern Tarderia fault, G G to the Gravina fault, $L$ to the Linera fault, M M the MascaluciaTremestieri fault, $\mathrm{N}$ the Nizzeti fault, R R the Ragalna fault, $\mathrm{F}$ the Fiandaca-Pennisi Faults, $\mathrm{T}$ to the Timpe faults, $\mathrm{Td}$ to the two western Tarderia faults, and $\operatorname{Tr}$ to the Trecastagni fault. See text for further details. 
394 4.1.5 Mascalucia-Tremestieri, Trecastagni \& Gravina fault systems

395 Curved faults of similar orientation are found in the same position as the Mascalucia-Tremestieri fault in about half of the experiments in Table II; the appearance of these model faults can be seen, marked $\mathrm{M}$, in the simulations of Fig. 5 . In each case they extend much further towards the cone than the surface exposures on Etna, joining the bounding faults of the summit graben. This corresponds to the similar northward extension of the Mascalucia-Tremestieri fault as far as the southern rift visible in radar interferograms (Froger et al. 2001, Ranvier 2004, Bonforte et al. 2011). A feature marked $\operatorname{Tr}$ corresponding to the straighter Trecastagni fault is also visible to the north, that joins the Mascalucia-Tremestieri fault analogue close to the bottom right corner of the models, this junction being rather further east than the real Trecastagni fault. In most models a fainter and more discontinuous curved fault $\mathrm{G}$ southeast of the Mascalucia-Tremestieri fault analogue and parallel to it matches the position of the Gravina fault. Although experiments 7 and 11 (top and middle right, fig. 5) reproduce the three systems reasonably correctly, experiment 8 (Fig. 5 lower left) has an additional fault, marked ? that has not been observed on Etna, though one section of it (marked $\mathrm{N}$ ) where it is joined to the north by a north-south fault $F$ does resemble the Nizzetti fault in position and orientation, where it is joined by the southward extension of the Fiandaca-Pennisi Faults.

Like their counterparts on Etna, all three of these faults show distinct right lateral motion during the lifetime of each experiment. This is particularly well visible in the end state of experiment 7 (middle right Fig. 5), where the less pronounced north-south faults crossing each of them have been clearly displaced right-laterally. Again, their functioning seems to be identical to the corresponding trio of faults on Etna: similar to the Pernicana fault in the north, they mark the boundary between the relatively stationary western sector of the flanks where downslope and spreading motion are of similar magnitude and cancel each other out, and the rapid surface motion on the eastern side, where spreading and downslope sliding motion are summed.

In all of the models, these faults develop initially from fractures on the south slopes of the sand cones, which appear quickly soon after the start. These fractures then spend a much longer time gradually propagating southeastwards in the later stages of the experiment. In the picture of Experiment 12 after 50 minutes (Fig. 5 lower left), an analogue of the Trecastagni fault is starting to develop, but a Mascalucia-Tremestieri analogue has a long way still to go, and there is no clear sign of an analogue of the Gravina fault. On Etna, all faults on the summit cone or close to it have a higher chance of being buried under recent lavas or ash falls, so may not be visible unless very recent.

\subsubsection{Ragalna faults}

Faulting of similar appearance and position to the Ragalna fault system is present in all but two of the experiments. In Fig. 5 these have been marked R. In the final phase of one of these simulations, experiment 7, this fault system has joined the Gravina fault to form a single curved fault marking the southwestern boundary of tectonic activity in the model. This is in line with the conclusions of Rust \& Neri (1996), though it should be noted that this does not happen in experiments 7 or 11. 
Measurements of strike-slip displacement and extension were made across model faults that were well matched in shape and position to those of Etna. Two experiments, 7 and 11, gave good analogues of most of the major faulting systems so that comparative velocities throughout the model could be derived for each fault system.

The left-lateral displacement of analogues of the Pernicana fault was clearly visible in most experiments, and rates of slip ranged from 9 to $33 \mathrm{~mm} \mathrm{~h}^{-1}$, with an average of $19.8 \mathrm{~mm} \mathrm{~h}^{-1}$. These millimetres per hour values were converted to millimetres per year displacement velocities measured in the field on Etna (see above, sections 2.2 to 2.6), which are best represented by the value of $27 \mathrm{~mm} \mathrm{y}^{-1}$ measured throughout the Holocene (Tibaldi \& Gropelli 2002). Using the simple relation $v_{f} / v_{m}$, where $v_{f}$ is the observed field strike-slip velocity of the Pernicana fault and $v_{m}$ is the strike-slip velocity of its model counterpart gives a factor of $x 11950$ model to field, which is used to scale the measurements of the other model fault systems in Table III and the rest of this section.

The images of the three parallel model faults similar to the Trecastagni, the Mascalucia-Tremestieri and the Gravina fault were also measured (Fig. 5). Model faults simulating the Trecastagni fault gave scaled right-lateral strike-slip velocities of 4.6 to $8.5 \mathrm{~mm} \mathrm{y}^{-1}$, which compare with 2 to $5 \mathrm{~mm} \mathrm{y}^{-1}$ for the Trecastagni fault itself. In both model and field measurements, these values are lower than those of the Pernicana fault displacement velocity. Scaled displacement values for the model Mascalucia-Tremestieri fault are slightly larger at 4.9 to $9.6 \mathrm{~mm} \mathrm{y}^{-1}$, as are field values of 8 to $15 \mathrm{~mm}$ $\mathrm{y}^{-1}$. Analogues of the Gravina fault, the most southerly of the three, showed different scaled strikeslip velocities between models, varying from no detectable slip to $7.9 \mathrm{~mm} \mathrm{y}^{-1}$. Field displacement measurements of the Gravina fault itself also varied, from 5 to $15 \mathrm{~mm} \mathrm{y}^{-1}$.

Model analogues of the main north-south faults of the Ragalna fault system provided measurements of both extension across the fault and right-lateral strike-slip where this was detectable. Scaled extension varied between 1 and $2.6 \mathrm{~mm} \mathrm{y}^{-1}$, and strike-slip from 0 to $1.7 \mathrm{~mm} \mathrm{y}^{-1}$. Field measurements of extension were between 3.5 and $4 \mathrm{~mm} \mathrm{y}^{-1}$, and strike-slip 4 to $5 \mathrm{~mm} \mathrm{y}^{-1}$.

The sum of the mean velocities of the three southern right-lateral transcurrent faults in the models totals $21.7 \mathrm{~mm} \mathrm{y}^{-1}$; or $23.8 \mathrm{~mm} \mathrm{y}^{-1}$ if the western (corresponding to Ragalna) fault is included. This compares to field measurements totalling $24 \mathrm{~mm} \mathrm{y}^{-1}$, or $28.5 \mathrm{~mm} \mathrm{y}^{-1}$ including the Ragalna faults. It is interesting that both model and field values summed are close to those of the Pernicana fault and its equivalent in the north, emphasising the point made earlier that the three or four southern faults fulfil the same function as the Pernicana fault in the north, with the strain release being distributed between three or four faults instead of one.

The extension across the north-south summit graben, visible across the sand cone of every experiment, was difficult to measure in many cases because the cone became broken up by the faulting, making reference points impossible to locate in successive images. Two models, 7 and 11, could be used, which gave scaled extension rates of 27 and $28 \mathrm{~mm} \mathrm{y}^{-1}$, of similar order to the Pernicana fault analogues. By contrast, the summit graben of Etna shows long term extension 19802018 of 179 to $229 \mathrm{~mm} \mathrm{y}^{-1}$. This is an order of magnitude greater than the Pernicana fault, so the model summit graben have much smaller relative extension rates than on Etna. The measurements of each of the model faults described above are given in Table III below, and compared to measurements from their counterparts on Etna, with references to field measurements in each case. 
Table III Measured displacement rates for model faults and their counterparts on Mt Etna. Model values in $\mathrm{mm} \mathrm{y}^{-1}$ are scaled up to Etna values in $\mathrm{mm} \mathrm{y}^{-1}$ by using the Holocene values for the Pernicana fault strike slip rate as a standard, giving a conversion factor of x11950 model to Etna.

\begin{tabular}{|c|c|c|c|c|c|c|c|c|c|c|c|c|}
\hline \multirow[t]{3}{*}{ Model Fault } & \multirow{2}{*}{$\begin{array}{l}\text { Type of } \\
\text { isplacement }\end{array}$} & \multirow{2}{*}{$\begin{array}{l}\text { Exp } 7 \\
\text { last }\end{array}$} & \multirow{2}{*}{$\begin{array}{c}\text { Exp } 11 \\
\text { last }\end{array}$} & \multicolumn{2}{|c|}{$\operatorname{Exp} 7 \operatorname{Exp} 9$} & \multicolumn{2}{|c|}{$\operatorname{Exp} 11 \operatorname{Exp} 13$} & 3 Mean & \multirow{2}{*}{\multicolumn{2}{|c|}{$\begin{array}{l}\text { Mean model Etna } \\
\text { values scaled field }\end{array}$}} & \multirow{2}{*}{$\begin{array}{c}\text { period of } \\
\text { time }\end{array}$} & \multirow[t]{2}{*}{ References } \\
\hline & & & & first & & last & & Raw & & & & \\
\hline & & $191 \mathrm{~m}$ & $19 \mathrm{~m}$ & $46 \mathrm{~m}$ & & $44 \mathrm{~m}$ & & $\mathrm{~mm} \mathrm{~h}^{-1}$ & $1 \quad m m y^{-1}$ & $m m y^{-1}$ & & \\
\hline Summit graben opening north & extension & 5.9 & & 17.4 & & 22.7 & & 20.0 & 27.2 & 229 & $1980-2018$ & Murray 2019 \\
\hline Summit graben opening south & extension & & & 16.9 & & 24.5 & & 20.7 & 28.2 & 179 & $1980-2018$ & \\
\hline Mean Summit Graben & extension & & & & & & & 20.4 & 27.7 & 204 & \pm 25 & \\
\hline Pernicana: Monte Pizzillo & left-lateral & & & & & & 18.8 & 18.8 & 25.6 & $26 \pm 5$ & $1874-1996$ & Garduno et al. 1997 \\
\hline Pernicana: Piano Provenzana & left-lateral & & & & & & & & & $27 \pm 7$ & $13700 y$ & Tibaldi \& Gropelli 2002 \\
\hline Pernicana: Mareneve & left-lateral & 9.1 & 27.9 & 21.6 & 15.5 & 17.3 & & 18.3 & 24.9 & 19 & pre 2002 & Neri et al 2004 \\
\hline Pernicana: Presa & left-lateral & & 33.2 & 17.6 & 15.0 & 21.4 & 19.8 & 21.4 & 29.1 & 8 to 18 & pre 2002 & Neri et al 2004 \\
\hline Mean Pernicana & Left-lateral & & & & & & & 19.8 & 27.0 & 27.0 & \pm 9 & \\
\hline Trecastagni: at Trecastagni & Right lateral & 5.0 & 13.5 & 1.3 & & 6.2 & & 6.5 & 8.8 & 2 to 5 & 1993-1997 & $\begin{array}{l}\text { Froger et al 2001, } \\
\text { Ranvier } 2004\end{array}$ \\
\hline Trecastagni: at Catania plain & Right lateral & 3.3 & 10.6 & 5.4 & & 6.0 & & 6.3 & 8.6 & & & \\
\hline Mean Trecastagni & Right-lateral & & & & & & & 6.4 & 8.7 & 3.5 & \pm 2 & \\
\hline $\begin{array}{l}\text { Mascalucia-Tremestieri: at } \\
\text { Tremestieri }\end{array}$ & Right lateral & 4.0 & 4.7 & 3.4 & & 4.3 & & 4.1 & 5.6 & 8 to 10 & 1993-1997 & $\begin{array}{l}\text { Froger et al 2001, } \\
\text { Ranvier } 2004 \text {, Bonforte } \\
\text { et al } 2011\end{array}$ \\
\hline $\begin{array}{l}\text { Mascalucia-Tremestieri: at } \\
\text { Catania plain }\end{array}$ & Right lateral & 3.2 & 6.8 & 3.6 & & 9.4 & & 5.7 & 7.8 & 15 & $1995-2000$ & Bonforte et al 2011 \\
\hline Mean Mascalucia-Tremestieri & i Right-lateral & & & & & & & 4.9 & 6.7 & 9 & \pm 4 & \\
\hline Gravina: near Gravina & Right lateral & 3.1 & 10.9 & 0.0 & & 5.4 & & 4.9 & 6.6 & 8 to 15 & $1993-2000$ & $\begin{array}{l}\text { Froger et al } 2001 \text {, } \\
\text { Ranvier } 2004 \text {, Bonforte } \\
\text { et al } 2011\end{array}$ \\
\hline Gravina: at Catania plain & Right lateral & 2.9 & 7.9 & 1.1 & & 5.8 & & 4.4 & 6.0 & 5 & $1995-2000$ & Bonforte et al 2011 \\
\hline Mean Gravina & Right-lateral & & & & & & & 4.6 & 6.3 & 11.5 & \pm 6 & \\
\hline Ragalna: north & extension & & 2.9 & & & & & 2.9 & 4.0 & & 1999-2005 & Neri et al 2007 \\
\hline Ragalna: south & extension & 2.6 & 2.1 & 0.8 & & 1.9 & & 1.8 & 2.5 & 3.5 to 4 & 1999-2005 & Neri et al 2007 \\
\hline Ragalna: south & Right-lateral & 1.7 & & 1.3 & & 1.6 & & 1.5 & 2.1 & 4 to 5 & 1999-2005 & Neri et al 2007 \\
\hline Mean Ragalna & Right-lateral & & & & & & & 1.5 & 2.1 & 4.5 & \pm 0.5 & \\
\hline Mean Ragalna & extension & & & & & & & 2.0 & 2.8 & 3.8 & \pm 0.3 & \\
\hline
\end{tabular}

478 In this table, none of the field measurements except the Pernicana fault and the summit graben

479 cover a period of more than six years of cumulative movement, so may not be representative of 480 annual rates measured over long periods of time. Despite this caveat, in general there is a similar 481 picture of distribution of velocities in the various sectors of the volcano with one exception: the 482 summit graben. The comparatively much higher rates of extension across the summit graben of 483 Etna are doubtless due to the additional force of magma pressure from the persistent injection of 484 dykes, mainly oriented north-south, as discussed below in section 5.2. All the clear-cut extension 485 events across the graben occurred during the injection of new dykes at the start of fissure eruptions, 486 when sudden increases of up to 4.42 metres occurred during a single eruption (Murray 2019). The 487 magma pressure from dyke injection created narrow areas of surface uplift alongside the dykes, 488 though in most cases these disappeared in subsequent subsidence events.

5. Discussion 
491 There are many limitations to the application of our experimental approach to the real situation on

492 Etna. The volcanic edifice is built on basement topography that is not a sloping plane, but a preexisting landscape with hills and valleys (Ogniben 1966, Branca \& Ferrara 2013). Also, the basement is made up of different rock units, each with its own different properties, rather than a layer of uniform thickness and material behaviour. The lava apron surrounding the Etna summit cone is also not of uniform thickness, but thins steadily away to nothing in distal regions, except to the east where it fills a prominent sub-Etnean valley (Branca \& Ferrara 2013). Neither is the summit cone of Etna conical, but elongated north-south due to the Northeast Rift and the Piano del Lago, and with the $5 \mathrm{~km}$ wide and $1 \mathrm{~km}$ deep valley of the Valle del Bove on its eastern side. Another major difference is that our models contain no equivalent of magma pressure, which clearly increases gravitational spreading at the summit in the long term (Murray 2019). There is also the fact that the continuing activity and output of the volcano and consequent rebuilding of the summit cone during the structural evolution of its flanks is not represented in the model. Despite these limitations, the models do provide the general structural and lithological context of Etna, and thus a generalised understanding of the fault systems produced by the specific configuration. They provide the mechanics of the general framework, but not the intricate details, and below we describe various modifications that take into account some details, and produce better fits.

\subsubsection{Basement topography representation}

Attempts were made to mitigate the effects of some of these drawbacks in some of the models. Firstly, the fact that the basement beneath Etna steepens from west to east (Branca \& Ferrara 2013) is represented in experiment 2 by a step on the east side of the sand cone. The silicon putty was allowed to flow off the eastern edge of the board representing the basement onto the bench below. This rather crude attempt to create slope change in a single step was not particularly successful, with less than half the Etna faults represented. In experiment 8, the basement board was curved so that the slope gradually increased eastward from about $1^{\circ}$ to $3^{\circ}$, which is closer to the real situation on Etna. This produced a much better fit, with analogues of $80 \%$ of Etna faults appearing.

In experiment 7, the downslope valleys in sub-Etna topography were represented by slightly curving the basement board to make an east-west valley $7 \mathrm{~mm}$ deep. This experiment was also one of the most successful, with $94 \%$ of Etna fault systems represented in the model (Fig. 5). Four experiments were adapted to better correspond to the thinning of the lava apron away from the summit cone. Although still planar rather than conical, the surface of the sand apron was thinned to the east in experiments 10 and 11, and to the southeast in experiments 12 and 13. In experiment 13 the sand apron thins to zero in the southeast corner (equivalent to the position of Catania on Etna). These experiments had mixed success, with experiments 10 and 12 at $25 \%$ and $30 \%$, but 11 and 13 both achieving analogues of over $60 \%$ of Etna faults (Figs. 4 and 5).

\subsubsection{Representation of Etna's irregular summit cone}

In three of the experiments, $10,11 \& 14$, an elongated sand cone was created to better represent the present shape of Etna, and in experiment 14 a valley was scooped out of the east side of the sand cone to represent the Valle del Bove. These too had mixed success, but 11 and 14 both showed reasonable representations of $63 \%$ of the Etna faults.

5.2 Magma pressure and persistent dyke intrusion 
Despite these drawbacks, it is clear that the configuration of most of the faults on Etna can be explained by the interaction of two processes alone: the gravitational spreading of the Etna summit cone (Borgia et al 1992) combined with the seaward sliding of the entire Etna massif down its sloping basement (Murray et al. 2018). But a third process, magma pressure, is required to explain the fact that the lateral east-west expansion of the summit graben of Etna exceeds that of the models by an order of magnitude. Further clues as to how gravitational and magmatic processes interrelate were mentioned in sections 4.1.1 and 4.1.2, where it was noted that some of the bounding faults of summit graben in the analogue experimental models are at similar positions and orientations to fractures formed during the 1947, 1983, 1985, 1989, 1991-3, 2001 and 2002 flank eruptions of Etna. This is good evidence that the combination of spreading and downslope sliding is controlling the position of future eruptive vents by creating fractures and weaknesses that become the paths of least resistance for later intruding magmas, not just for north-south eruptive fissures, but in other orientations as well. This assertion carries with it the implication that forecasting the location of future eruptive vents might be possible by GNNS monitoring of an array of stations in the summit region, to detect sectors where circumferential strain is increasing, and therefore likely to favour crack propagation and intrusion (Wadge, 1976).

The constant intrusion of radial dykes over time, particularly near the summit but including those that feed eruptions low down on the flanks, means that space must be found for these dykes (Walker 1992). Such intrusions always exert magma pressure normal to the dyke, which persistently results in widening (Murray 1990, 1994) that in turn results in overall expansion of the volcano. Magma pressure from the intrusions is therefore substantially augmenting extension velocity in a single feedback loop.

The addition of material at the cone summit whilst the experiment was continuing, to represent the persistent continuing output of the Etna, would have increased the mass of the summit cone, which in turn would have had the effect of increasing the gravitational spreading in the later stages of the experiment. This and the similar effects of magma pressure may have altered the configuration of some of the faults as a result, increasing the effects of spreading at the expense of the effects of sliding.

\subsection{Regional tectonics; East flank instability}

Regarding the effect of regional tectonism, it is true that the millennial fault displacements of those Sicilian faults that pass beneath the Etna summit and flanks must be continuing. An idea of how much these movements contribute to observed fault displacement at the surface may be gauged from field determinations of displacements around Etna, which vary from 0.9 to $1.4 \mathrm{~mm}^{-1}$ for the Holocene (Valensise and Pantosti, 1992; Monaco et al.,1997). They are therefore smaller than all the field-measured slip rates of the Etna fault systems, by up to two orders of magnitude. This is strong evidence that regional movements are minor effects, largely overwhelmed by the processes described in this paper.

The instability of the eastern flank has dominated thinking on the structure of Etna over the past three decades. The analogue modelling described in this paper provides a framework to understand this phenomenon. Fig. 3 shows a typical experiment at the start (left) and after 50 minutes (right). Gravitational spreading has been obstructed by the sand barrier to the north, west and south of the sand cone, but allowed to flow freely down the slope to the east. This dichotomy is emphasised by 
the fact that all westward spreading is upslope, where sliding and spreading are operating in contrary directions so tend to cancel each other out, whereas to the east of the cone, spreading and downslope motion are summed. The outcome has been the almost stationary regions all around the cone except eastward, in which direction progress over the ductile layer beneath has been rapid. The inevitable consequence has been arcuate faulting of the brittle sand apron to the northeast and south of the cone, tectonically cutting off an easterly mobile sector. This simple combination of events offers both a description and explanation of the rapid eastward movement of the eastern flanks of Etna, and the difference between this and the comparatively stable ground to the north and west, a dichotomy known as the east flank instability.

\section{Conclusions}

The structural faults on the summit and flanks of Mt Etna volcano originate principally from the two processes of gravitational spreading and the sliding of the Etna massif down its sloping basement. As such, Etna behaves as a mountain built on foundations unable to support it. What happens in the upper magmatic system is controlled by this framework.

The Peloritani mountains obstruct the gravitational spreading of the Etna cone northwards, and the southeast end of this mountain range marks the end point of obstruction. The abrupt change between stationary ground to the north, and the rapid eastward movement to the south where downslope sliding is added to gravitational spreading of the cone, results in the creation of the Pernicana fault, whose left-lateral strike-slip movement has the highest average velocity of the flank fault displacements of Etna.

The three transcurrent faults southeast of Etna, the Trecastagni, Mascalucia-Tremestieri and Gravina faults, are the result of a similar situation, in which the low range of hills along the southern edge of Etna also obstructs spreading, but being nearly twice as far from the summit cone, the tectonic strain release is spread between three faults, whose right-lateral displacement is individually less than the Pernicana, but summed together they are of similar velocity.

Together, the Pernicana and these southern faults tectonically cut off the more stable regions southwest, west and north of the volcano from the mobile eastern sector, generally termed the east flank instability.

The Ragalna fault system has started to propagate from the foot of the summit cone in a similar way to the three southern transcurrent faults, but as yet has failed to reach as far, but may do so in the future.

The Timpe faults result from the extension created by the downslope sliding and spreading of the eastern flank, as well as the submarine instability of the Etnean continental margin. Their orientation is sensitive to local changes in spreading direction.

The summit graben of Etna is the product of gravitational spreading of the cone, producing leaf graben that are suppressed in the east-west direction by tension consequent upon downslope sliding, but augmented in the north-south direction. 
The ability of simple non-magmatic analogue models to recreate all the Etnean faults is significant, in that it shows clearly that the faulting and deformation has its origin in gravity.

The additional process of the intrusion of magma is also controlled by gravitational spreading and sliding, which creates the cracking and faulting that intruding magma later follows. It might therefore be possible to detect the location of future eruptive vents by monitoring of an array of geodetic stations in the summit region to detect sectors of increasing tensional strain.

Lateral magmatic pressure from intrusive episodes dominates extension velocities at the summit of Etna, increasing graben opening by an order of magnitude compared to the scaled velocities of the analogue models in a feedback loop. On the flanks, model velocities of fault displacement match field measurements from Etna, indicating the limited effects of magma pressure elsewhere.

The faulting provides the framework in which to understand other Etnean activity, notably the hazards of eruptions, earthquakes and landslides.

\section{Acknowledgements}

We thank Dr S. Caffo and also the Parco dell'Etna, Corpo Forestale, Aziende Foreste, Sindaco di Comune di Linguaglossa and the Osservatorio Astrofisico (Catania), for permission to work on their land. We thank Martino Claudia for assistance with the laboratory analogue modelling in 2018. The fieldwork was supported by the U.K. Natural Environment Research Council (1975-1980, 1987-8, 1996-7, and more recently, grants NER/A/S/2001/00686, NER/A/S/2002/00411, NER/A/S/2003/00105, NE/D001390/1 and NE/E007589/1); CNRS, France (1981-1986); NATO (19881991); and the EEC (1992-8). The NERC Geophysical Equipment Facility loaned GPS kits (loan Nos. $727,776,799,825,869,898$ and 929).

\section{References}

Acocella, V., Neri, M., Norini, G., 2013. An overview of experimental models to understand a complex volcanic instability: Application to Mount Etna, Italy. J. Volcanol. Geotherm. Res. 251, 98111

Borgia, A., Ferrari, L., Pasquarè, G., 1992. Importance of gravitational spreading in the tectonic and volcanic evolution of Mount Etna. Nature 357, 231-235.

Borgia, A., 1994, Dynamic basis of volcanic spreading. J. Geophys. Res. 99, 17,791-17,804.

Branca, S., Coltelli, M., Groppelli, G., Lentini, F., 2011a. Geological map of Etna volcano, 1:50,000 scale. Ital. J. Geosci. 130 (3), 265-291. doi: http://dx.doi.org/10.3301/IJG. 2011.15

Branca, S., Coltelli, M., Groppelli, G., 2011b. Geological evolution of a complex basaltic stratovolcano: Mount Etna, Italy. Ital.J.Geosci. (Boll.Soc.Geol.It.) 130 (3), 306-317. doi: 10.3301/IJG.2011.13 
Branca, S., Ferrara, V., 2013. The morphostructural setting of Mount Etna sedimentary basement (Italy): Implications for the geometry and volume of the volcano and its flank instability.

Tectonophysics 586, 46-64.

Branca, S., De Beni, E., Chester, D., Duncan, A., Lotteri, A., 2017. The 1928 eruption of Mount Etna (Italy): Reconstructing lava flow evolution and the destruction and recovery of the town of Mascali. J. Volcanol. Geotherm. Res. Volgeo(2017) doi: 10.1016/j.jvolgeores.2017.02.002

Bonaccorso, A., Bonforte, A., Guglielmino, F., Palano, M., Puglisi, G., 2006. Composite ground deformation pattern forerunning the 2004-2005 Mount Etna eruption. J. Geophys. Res. 111, B12207. http://dx.doi.org/10.1029/2005JB004206

Bonaccorso, A., Currenti, G., Del Negro, C., 2013. Interaction of volcano-tectonic fault with magma storage, intrusion and flank instability: A thirty years study at Mt. Etna volcano. J. Volcanol. Geotherm. Res. 251, 127-136.

Bonforte, A., Bonaccorso, A., Guglielmino, F., Palano, M., Puglisi, G., 2008. Feeding system and magma storage beneath Mt. Etna as revealed by recent infation/deflation cycles. J. Geophys. Res. 113, B05406. http://dx.doi.org/10.1029/2007JB005334 2008.

Bonforte, A., Guglielmino, F., Coltelli, M., Ferretti, A., Puglisi, G., 2011. Structural assessment of Mount Etna volcano from permanent scatterers analysis. Geochem. Geophys. Geosyst. 12. https://doi.org/10.1029/2011GC003213.

Cristofolini, R., Fichera, R., Patané, G. 1981. Osservazioni morfotettoniche sul settore occidentale dell'Etna. Geografia Fisica e Dinamica Quaternaria 4, 55-63.

De Beni E., Branca, S., Coltelli, M., Groppelli, G., Wijbrans, J. 2011. Ar39/Ar40 isotopic dating of Etna volcanic succession. It. J. Geosci. (Boll. Soc. Geo. It.) 130, (3),292-305, doi: 10.3301/IJG.2011.14.

Ferruci, F., Patané, D., 1993. Seismic activity accompanying the outbreak of the 1991-1993 eruption of Mt. Etna (Italy). J. Volcanol. Geotherm. Res. 57, 125-135.

Ferruci, F., Rasá, R., Gaudiosi, G., Azzaro, R., Imposa, S., 1993. Mt Etna: a model for the 1989 eruption. J. Volcanol. Geotherm. Res. 56, 35-56.

Froger J.-L., Merle, O., Briole, P., 2001. Active spreading and regional extension at Mount Etnaimaged by SAR interferometry. Earth Planet. Sci. Lett. 187 (2001) 245-258

Garduño, V.H., Neri, M., Pasquarè, G., Borgia, A., Tibaldi, A., 1997. Geology of the NE-Rift of Mount Etna (Sicily, Italy). Acta Vulcanol. 9, 91-100.

Grindley, G.W., 1973. Structural control of volcanism at Mount Etna. Phil. Trans. R. Soc. Lond. A. 274, 165-175.

Gross, F., Krastel, S., Geersen, J., Behrmann, J. H., Ridente, D., Chiocci, F. L., et al. 2016. The limits of seaward spreading and slope instability at the continental margin offshore Mt Etna, imaged by highresolution 2D seismic data. Tectonophysics $667,63-76$. 
681 Lo Giudice, E., Patanè, G., Rasá, R., Romano, R. 1982. The structural framework of Mt Etna. Mem. 682 Soc, Geol. It. 23, 125-158.

683 Lo Giudice, E., Rasà, R., 1992. Very shallow earthquakes and brittle deformation in active volcanic areas: The Etnean region as an example. Tectonophysics 202, 257- 268.

Merle, O., Borgia, A., 1996. Scaled experiments of volcano spreading. J. Geophys. Res. 101, 13,805$68613,817$.

Merle, O., Lénat, J.-F., 2003. Hybrid collapse mechanism at Piton de la Fournaise volcano, Reunion Island, Indian Ocean. J. Geophys. Res. 108, B3, 2166, doi: 10.1029/2002JB002014.

Monaco, C., Tapponnier, P., Tortorici, L., Gillot, P.Y., 1997. Late Quaternary slip rates on the Acireale-Piedimonte normal faults and tectonic origin of Mt. Etna (Sicily). Earth Planet. Sci. Lett. 147, 125-139.

Murray, J.B., 1990. High-level magma transport at Mt Etna volcano, as deduced from ground deformation measurements. Chapter 17 of Magma Transport \& Storage, Ed. Ryan, John Wiley \& Sons Ltd., pp 357-383.

Murray, J.B., Voight, B., Glot, J.-P., 1994. Slope movement crisis on the east flank of Mt Etna volcano: Models for eruption triggering and forecasting. Engineering Geology 38, 245-259.

Murray, J.B., 1994. Elastic model of the actively intruded dyke feeding the 1991-1993 eruption of Mt Etna, derived from ground deformation measurements. Acta Vulcanologia 4, 97-99.

Murray, J.B., van Wyk de Vries, B., Pitty, A., Sargent, P.T.H., Wooller, L.K., 2018. Gravitational sliding of the Mt. Etna massif along a sloping basement. Bull. Volcanol. 80: 40. doi:https://doi.org/10.1007/s00445-018-1209-1.

Murray, J.B. 2019. The cryptic summit graben of Mt Etna volcano. J. Volcanol. Geotherm. Res. 387, https://doi.org/10.1016/j.jvolgeores.2019.07.024

Neri, M., Acocella, V., Behncke, B., 2004. The role of the Pernicana Fault System in the spreading of Mount Etna (Italy) during the $2002-2003$ eruption. Bull. Volcanol. 66, 417 - 430, doi:10.1007/s00445-003-0322-x

Neri, M., Guglielmino, F., Rust, D., 2007. Flank instability on Mount Etna: radon, radar interferometry, and geodetic data from the southwestern boundary of the unstable sector. J. Geophys. Res. 112, B04410 http://dx.doi.org/10.1029/2006JB004756.

Obrizzo, F, Pingue, F., Troise, T., De Natale, G., 2001. Coseismic displacements and creeping along the Pernicana fault (Etna, Italy) in the last 17 years: a detailed study of a tectonic structure on a volcano. J. Volc. Geotherm. Res., 109, 109-131.

Ogniben, L., 1966. Lineamenti idrogeologici dell'Etna. Rivista Mineralogica Siciliana XVII, N.100-102, 151-174. 
R. Azzaro, Bonforte, A., D'Amico, SD., Guglielmino, F., Scarfi, L., 2020. Stick-slip vs. stable sliding fault behaviour: A case-study using a multidisciplinary approach in the volcanic region of Mt. Etna (Italy). Tectonophysics 790 doi.org/10.1016/j.tecto.2020.228554.

Ranvier, F. (2004). Modélisation numérique des mouvements de flanc de l'Etna (Sicile, Italie) mis en evidence par interférométrie radar. Thesis for Docteur d'Université, Université Blaise Pascal, France, $277 \mathrm{pp}$.

Rasá, R., Azzaro, R., Leonardi, O., 1996. Aseismic creep on faults and flank instability at Mt. Etna volcano. In: McGuire, W.J., Jones, A.P., Neuberg, J. (Eds.), Volcano instability on the Earth and other planets. Geol. Soc. Spec. Publ. 110, 179-192.

Rittmann, A., 1973. Structure and evolution of Mount Etna. Phil. Trans. R. Soc. Lond. A. 274, 5-16.

Rust, D., Neri, M., 1996. The boundaries of large scale collapse on the flanks of Mount Etna, Sicily. In: McGuire, W.J., Jones, A.P., Neuberg, J. (Eds.), Volcano instability on the Earth and other planets. Geol. Soc. Spec. Publ. 110, 193-208.

Tibaldi, A., Gropelli, G., 2002. Volcano-tectonic activity along structures of the unstable NE flank of Mt. Etna (Italy) and their possible origin. J. Volcanol. Geotherm. Res. 115, 277 - 302.

Urlaub, M., Petersen, F., Gross, F., Bonforte, A., Puglisi, G., Guglielmino, F., Krastel, S., Lange, D., Kopp, H. 2018. Gravitational collapse of Mount Etna's southeastern flank. Sci. Adv. 4, eaat9700.

Valensise, G., Pantosti, D., 1992. A 125 kyr-long geological record of seismic source repeatability: the Messina Straits (Southern Italy) and the 1908 earthquake (Ms 7.5). Terra Nova 4, 472-483.

Wadge, G., 1976. Deformation of Mt Etna 1971-1974. J. Volcanol. Geotherm. Res. 1, 237-263.

Walker, G.P.L., 1992. 'Coherent intrusion complexes' in large basaltic volcanoes-a new structural model. J. Volcanol. Geotherm. Res. 50, 41-54

Wooller, L.K., van Wyk de Vries, B., Murray, J.B., Rymer, H., Meyer, S., 2004. Volcano spreading controlled by dipping substrata. Geology 32, No.7, 573-576. doi: 10.1130/G20472 